\title{
Nematode infection among ruminants in monsoon climate (Ban-Lahanam, Lao PDR) and its role as food-borne zoonosis
}

\author{
Infecção por nematóides em ruminantes nas monçôes (Ban-Lahanam, RPD do Laos) \\ como zoonose transmitida por alimento
}

\begin{abstract}
Marcello Otake Sato ${ }^{1 *}$; Megumi Sato ${ }^{2}$; Kittipong Chaisiri³; Wanna Maipanich'; ${ }^{3}$ Tippayarat Yoonuann; Surapol Sanguankiat ${ }^{3}$; Tiengkham Pongvongsa ${ }^{4}$; Boungnong Boupha ${ }^{5}$; Kazuhiko Moji6; Jitra Waikagul ${ }^{3}$
\end{abstract}

${ }^{1}$ Escola de Medicina, Universidade Federal do Tocantins - UFT, Palmas, TO, Brasil

${ }^{2}$ School of Health Sciences, Faculty of Medicine, Niigata University, Japan

${ }^{3}$ Department of Helminthology, Faculty of Tropical Medicine, Mahidol University, Bangkok, Thailand

${ }^{4}$ Station of Malariology, Parasitology \& Entomology, Savannakhet Province, Lao PDR

${ }^{5}$ National Institute of Public Health, Ministry of Health, Lao PDR

${ }^{6}$ Research Institute for Humanity \& Nature, Kyoto, Japan

Received November 19, 2013

Accepted February 5, 2014

\begin{abstract}
Trichostrongylids infection has gained significant public health importance since Trichostrongylus spp. infections have been reported in humans in Lao PDR. In this study, gastrointestinal nematodes were identified and the intensity of infections was determined in goats and cattle, which are animals greatly used for meat production in Lahanam Village, Lao PDR. The total number of goats and bovines was 23 and 29, respectively, pertaining to 32 households surveyed in the area. Feacal samples were randomly collected from 14 goats and 11 bovines. Ninety three percent (13/14) of goats and 36\% (3/11) of cattle were infected, with an average of 1,728 and 86 eggs per gram of faeces (EPG), respectively. Coproculture showed Trichostrongylus spp. (goats 16\%; bovines 48\%), Haemonchus spp. (goats 69\%; bovines 37\%), Cooperia spp. (bovines 8\%) and Oesophagostomum spp. (goats 15\%; bovines 6\%). After performing the necropsy on an adult goat, Trichuris spp. was also found. We confirmed the presence of Oesophagostomum spp., H. contortus and T. colubriformis by morphology and DNA sequencing analysis of the ITS region of rDNA. Due to interactions between humans and goats in Lahanam Village and high EPG results, the diagnosis of species and the intensity of gastrointestinal nematode infection in these animals are important public-health issues. Other ruminant parasites, such as Oesophagostomum and Haemonchus, found in caprines and bovines, are reported to be causes of zoonosis and their presence in humans should be investigated in future field surveys in this area.
\end{abstract}

Keywords: Trichostrongylids, goats, bovines, foodborne zoonosis.

\section{Resumo}

Infecção por tricostrongilídeos ganhou significativa importância para a saúde pública, desde que infecçôes por Trichostrongylus spp. foram relatadas em humanos no Laos. Neste estudo, determinou-se a intensidade de verminoses gastrintestinais em caprinos e bovinos, importantes animais de produção na região de Lahanam Village, RPD do Laos. O número total de caprinos e bovinos foi 23 e 29, respectivamente, nas 32 famílias estudadas. Amostras de fezes foram coletadas, aleatoriamente, de 14 caprinos e 11 bovinos. Noventa e três por cento (13/14) dos caprinos e $36 \%$ (3/11) dos bovinos encontraram-se parasitados, com uma média de 1728 e 86 ovos por grama de fezes (OPG), respectivamente. Pela coprocultura, identificou-se Trichostrongylus spp. (caprinos 16\%; bovinos48\%), Haemonchus spp. (caprinos 69\%; bovinos 37\%), Cooperia spp. (bovinos 8\%) e Oesophagostomum spp. (caprinos 15\%; bovinos 6\%). A necropsia de um caprino registrou também a presença de formas adultas de Trichuris spp. Morfologicamente e por análise do sequenciamento da região ITS do rDNA, foi confirmada a presença de Oesophagostomum spp., H. contortus e T. colubriformis. Devido às interaçôes entre seres humanos e caprinos, em Lahanam Village, o alto OPG demonstrando o grau elevado de infecçáo por nematóides gastrintestinais nesses animais e a comprovaçáo de espécies causadoras de zoonoses, aponta-se uma importante questão de saúde pública. Outros parasitos de ruminantes, como Oesophagostomum e Haemonchus, encontrados nos caprinos e bovinos estudados, são também relatados como agentes de zoonose, e sua presença em seres humanos deve ser investigada em futuras pesquisas de campo no local.

Palavras-chave: Tricostrongilídeos, caprinos, bovinos, zoonoses transmitidas por alimentos.

\footnotetext{
*Corresponding author: Marcello Otake Sato

Escola de Medicina, 109 N, Av.NS15 Al.CNO 14,

CEP 77001-090, Palmas, TO, Brasil

e-mail: otake@uft.edu.br
} 


\section{Introduction}

Nematodes are an important group of parasites in ruminants. Due to their high prevalence and pathogenicity, the Strongyloidea (which includes trichostrongylids and strongilids) is considered the most important parasite group. The life cycle of these nematodes consist of larval stages in the environment and adults in the definitive hosts, which are passively infected by pasture feeding (HONER; VIEIRA-BRESSAN, 1992).

Clinical signs in animals with worm infections include hyporexia or anorexia and modification in the digestibility of food, due to damage caused to the digestive tract's lumen. These alterations are reflected by decreases in production and quality of milk and meat, in the host's work capacity and reproductive efficiency, and by the premature death of infected animals (HOLMES, 1985).

The characteristics of tropical and sub-tropical climates can facilitate the development of parasitic agents (PERRY; RANDOLPH, 1999). Lao PDR is located in a tropical area and has monsoon seasons; therefore, parasitic agents are considered to be a main cause of disease within production animals (thus reducing milk and meat production), as well as zoonosis in humans, as described previously (SATO et al., 2010, 2011; LATTES et al., 2011).

Although intestinal parasite infections in production animals are a well-known problem, there are still very few studies on this matter in Thailand (RATANAPOB et al., 2012) and in other countries in Southeast Asia, such as Lao PDR. The study area was located in Ban Lahanam, Savannakhet Province, a southern region of Lao PDR. Subsistence agriculture accounts for half of the country's GDP, and rice is the dominant agricultural product. Products from subsistence agriculture (such as goat and cattle) and also from forest exploitation (due to foreign demand for wild animals, and non-wood forest products for food and traditional medicines) are sold in city markets. This report describes the putative origin of human trichostrongylosis, a particularly important parasitic zoonosis in this region, and suggests haemonchosis and oesophagostomosis as possible zoonotic parasitic diseases in the studied area.

\section{Materials and Methods}

\section{Study area and sampling}

Faecal samples were collected from goats and cattle bred in the Ban Lahanam area (coordinates N16 16.120 E105 16.077), Savannakhet Province, Lao PDR, as detailed in the sampling map (Figure 1). Two field surveys were performed in August 2010, during the monsoon season. Samples were analysed at the Department of Helminthology, Faculty of Tropical Medicine, Mahidol University (Thailand); and molecular studies were conducted at the School of Health Sciences, Faculty of Medicine, Niigata University (Japan) and at the Animal Laboratory for Medical Sciences at the School of Medicine, Universidade Federal do Tocantins (Brazil).

The total number reported of goats and bovines in Ban Lahanam was 82 and 452, respectively (P. Tiengkham, personal communication, 2010). The sampling numbers of goats and
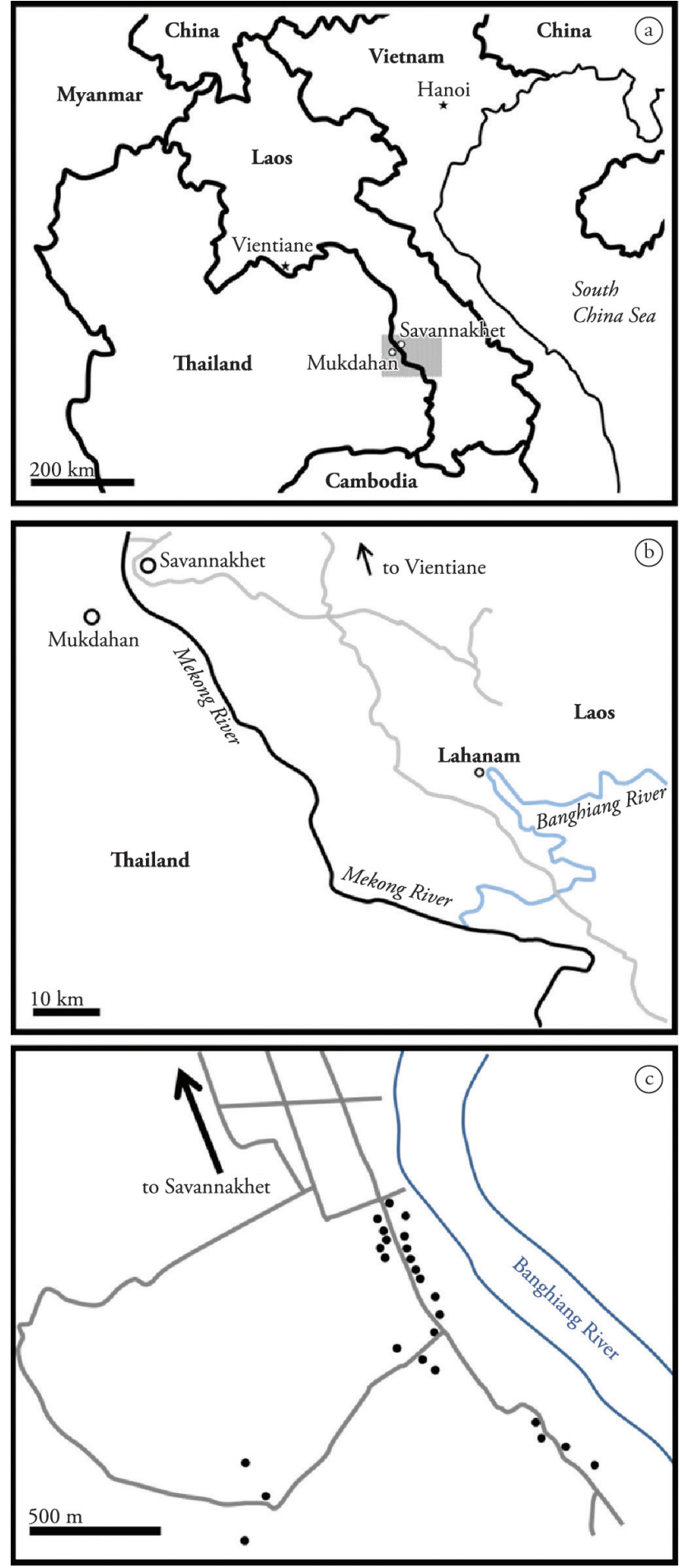

Figure 1. a) Map of Lao PDR and neighbouring countries. Star “\$” corresponds to Vientiane (Capital of Lao PDR) and Hanoi (Capital of Vietnam). Savannakhet City (Lao PDR) and Mukdahan City (Thailand) are indicated by white circles" $\circ$ ". b) Amplification of the hachured area of the "a" panel, with main routes (grey lines). Mekong River (thick black line) delineates Lao PDR/Thailand international border. Lahanam Village is indicated as a small white circle "O", near Banghiang River (blue line). c) Map of Lahanam Village showing study area. Black circles “•” indicate the 25 sampling spots, which correspond to all families owning goat/cattle in the study area. Streets are indicated by grey lines. Banghiang River is indicated by blue lines. 
bovines were estimated by the number of families surveyed in the area ( 32 households), that owned 23 goats and 29 bovines. They are raised extensively and share the same pasture area. Samples collected directly from the rectums, were taken randomly from the available animals ( 11 bovines and 14 goats) of 25 families that were breeding goats and/or cattle for meat production for their subsistence and selling in the local market, as shown in the sampling map (Figure 1c).

All study procedures were approved in advance by the Lao Medical Ethics Committee (172/NECHR).

\section{Parasitological Methods}

\section{Faecal examination}

Faecal examination was performed using a modified McMaster Technique (GORDON; WHITLOCK, 1939), using 2 grams of faeces and $28 \mathrm{ml}$ of saturated $\mathrm{NaCl}$ solution per sample. Diagnosis of gastrointestinal nematode infections was based on faecal egg counts (FECs), expressed in eggs per gram of faeces (EPG).

\section{Coproculture}

After the FECs were performed, faecal samples were subjected to coproculture (ROBERTS; O'SULLIVAN, 1950), using a pool of faeces separated per species per day. Samples were mixed with vermiculite and incubated at room temperature for eight days. After incubation, third-stage larvae (L3) were recovered by modified Baermann technique. The L3 were fixed in Lugol's solution and the nematodes' genus was identified under a light microscope, using the key described by Ueno and Gonçalves (1998). The percentage of each genus was obtained by counting a minimum of $200 \mathrm{~L} 3$.

\section{Necropsy}

One goat was euthanized and necropsied. The intestinal tract, from the abomasum to the rectum, was ligated and separated for counting and identification of adult worms. The recovered worms were washed in saline solution and stored in 70\% ethanol and formalin for molecular and morphological identification. In addition, post-mortem examination of all organs was carried out in order to identify any pathological processes that were present.

\section{DNA extraction, PCR and sequencing}

Genomic DNA was extracted from adult worms using a Wizard ${ }^{\oplus}$ Genomic DNA Purification Kit (Promega) and used as a template. Each species collected from naturally infected goats was identified based on the nucleotide sequence of the ITS amplified by PCR. A set of PCR primers was used for amplification, with the following sequences: 5-CTCGCTCTCAGTGTTTTCGT-3 (ITS forward), and 5-TTGACAAGTTAAGCAGCTTC-3 (ITS reverse) (GASSER et al., 1996). PCR was performed with GoTaq ${ }^{\circ}$ Master Mix (Promega). The PCR products were sequenced by ABI3730XL sequencer (Applied Biosystems, USA) at Macrogen Inc. (Seoul, Korea).
The sequences obtained were aligned and compared with the same ITS sequences from the GenBank database, using BioEdit version 7.1.3 (HALL, 1999). A phylogenetic tree was reconstructed using the neighbour-joining method with MEGA version 5.1 (KUMAR et al., 2004). The tree was evaluated by a bootstrap test based on 1,000 re-samplings (FELSENSTEIN, 1985).

\section{Results and Discussion}

The results showed that $93 \%$ of caprines and $36 \%$ of bovines were infected with trichostrongylids, with EPG averages of 1,728 and 86 for caprines and bovines, respectively. Trichuris spp. and Strongyloides spp. eggs were also observed in the faecal examinations.

When comparing the EPG data of cattle and goats (Figure 2), the overall distribution showed differences of infection intensity between the two species, with a median of 0 and 1,425 and a maximum value of 350 and 6,300 for cattle and goats, respectively. The data showed less variability for cattle (150) than goats (875). Even with different breeding (Caninde, Bhuj and Anglo-Nubian) values can be higher for goats, but not for cattle, as shown in other studies: Costa et al. (2000) with a mean EPG varying from 302 to 397 (lower than our average of 1,728 EPG), and other studies in goats conducted in Thailand and Bangladesh, with averages of 1,176 and 263 EPG, respectively (RATANAPOB et al., 2012; HASSAN et al., 2011). Our results were higher than other studies with periparturient animals, such as that of Sweeny et al. (2011), where a high worm egg count in Dorper lambs was associated with a lower body condition score. However, the animals did not present any clinical signs, perhaps due to the resilience to nematode infection, as reviewed by Chiejina and Behnke (2011) in Nigerian West African dwarf goats.

Coproculture results showed infection with Haemonchus spp. (69\%), Trichostrongylus spp. (16\%) and Oesophagostomum spp. (15\%) in caprines, and Haemonchus spp. (37\%), Cooperia spp. (8\%), Trichostrongylus spp. (48\%) and Oesophagostomum spp. (6\%) in bovines. These results are similar to other studies, but prevalence of Oesophagostomum spp. (15\%) in goats was much higher than

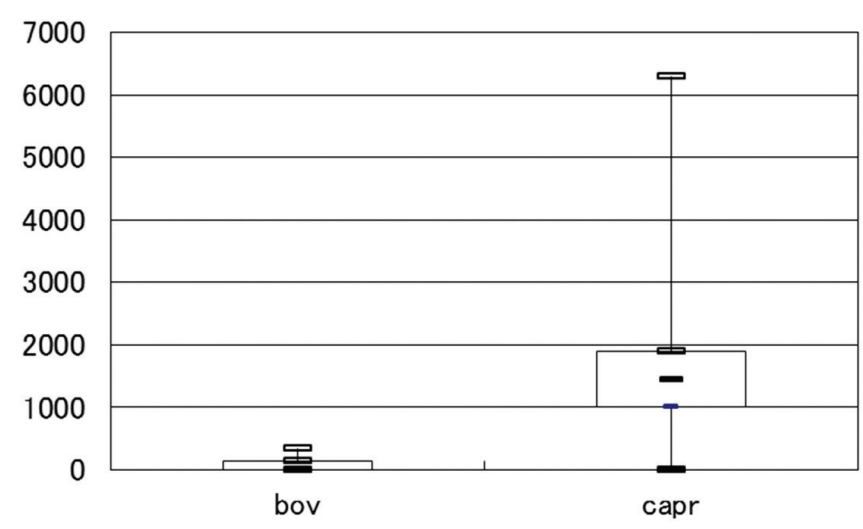

Figure 2. Boxplot comparing EPG data of cattle (bov) and goats (capr). The distribution of data shows the difference of infection intensity between the two species, with a median of 0 and 1,425 and a maximum value of 350 and 6,300 for cattle and goats, respectively. Data for cattle showed less variability (150) than goats (875). 


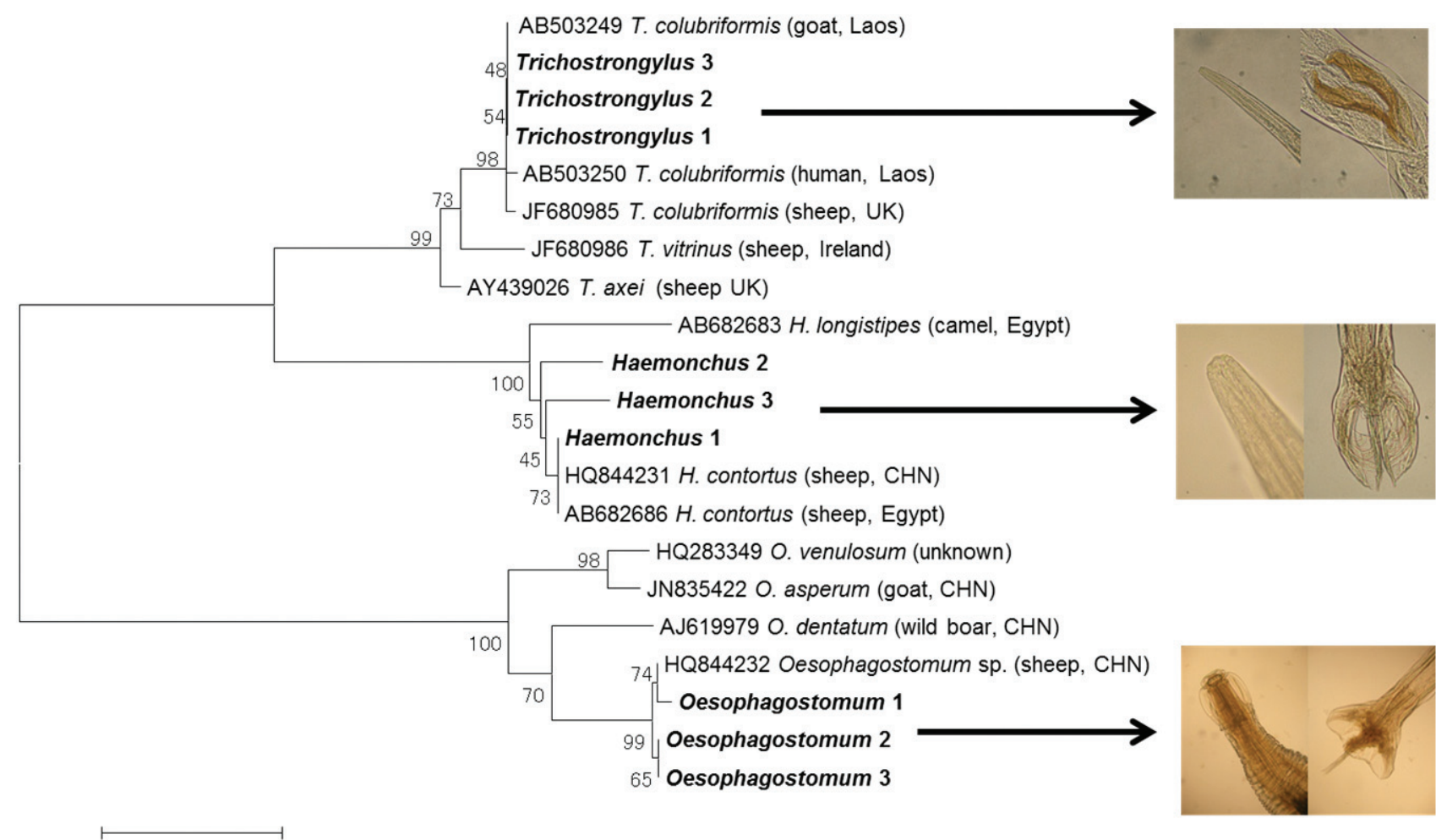

Figure 3. Phylogenetic tree using sequenced ITS2 of the recovered and morphologically diagnosed worms. The phylogenetic tree was reconstructed using the neighbour-joining method, and worms were photographed after phenol diaphanisation. The sequencing data (left side) confirmed the morphological diagnosis of Trichostrongylus, Oesophagostomum, and Haemonchus (right side).

that observed by Ahid et al. (2008) in Brazil at 7.3\%. It was also higher than that found in Norway, where L3 of Oesophagostomum/ Chabertia was only encountered at a very low frequency, with values $<1 \%$ (DOMKE et al., 2012).

Infection intensity is greater in caprines, with a much higher EPG count average than bovines. These results strongly suggest that larvae from goat faeces contaminate vegetables and fomites, and act as a main route of infection due to the interaction and close proximity of animals living near human domiciles.

After performing necropsy on one goat, adult worms were recovered and identified under a light microscope, using lactophenol diaphanisation. DNA was then extracted and ITS2 was successfully amplified and sequenced (DDBJ/EMBL/GenBank accession nos. AB908958-AB908966). The sequencing confirmed a morphological diagnosis of Trichostrongylus, Oesophagostomum and Haemonchus (Figure 3). Previous analysis of ITS sequences comparing human cases of trichostrongylosis with worms collected from goats showed $100 \%$ similarity (Figure 3), indicating humans were infected with L3 of Trichostrongylus (SATO et al., 2011). Since it was not possible to obtain worm DNA from cattle, we could not determine if cattle play a role in Trichostrongylus transmission to humans; however, due to the low level of nematode infection in bovines, as observed by EPG count (Figure 2), we may consider that low levels of environmental contamination by L3 result in a lower risk of human infection.

While Trichostrongylus infection in humans has already been reported in this area (SATO et al., 2010, 2011), there are no reports of oesophagostomosis and haemonchosis among humans in Laos. There is a high possibility of infection in Lahanam Village, since the way of infection could be similar for these species, and there are studies showing Haemonchus (GHADIRIAN; ARFAA, 1973) and Oesophagostomum (BLOTKAMP et al., 1993) infection in humans. More studies are required involving DNA confirmation of Strongyloidea eggs found in human faeces, because the severity of the pathogenicity of Haemonchus and Oesophagostomum can be more important than that caused by Trichostrongylus.

The infection rate of trichostrongylids in caprines is high, and infective larvae may spread to all areas in close proximity to houses, and also through contact with fomites, or nearby where vegetables are cultivated and eaten raw. There is a high potential for active transmission not only of Trichostrongylus spp., as described previously, but also of other animal nematodes in humans, such as Haemonchus and Oesophagostomum, as previously described (GHADIRIAN; ARFAA, 1973; BLOTKAMP et al., 1993). We recommend that these infections be considered an important issue for public health concern in Laos and other Southeast Asian countries.

\section{Acknowledgments}

We would like to thank the people of Lahanam Village for their kind cooperation. In addition, we would like to thank Mr. Nirandon Homsuwan from the Department of Helminthology, Faculty 
of Tropical Medicine, Mahidol University, and Ms. Vongphaka Boutsyhalath from the Health Center, Lahanam Village, Sonkon District, Savannakhet Province, Lao PDR, for their generous assistance in the field. This research was supported by the Research Institute for Humanity and Nature project 'Environmental Changes and Infectious Diseases in Tropical Asia', for Kazuhiko Moji.

\section{References}

Ahid SMM, Suassuna ACD, Maia MB, Costa VMM, Soares HS. Parasitos gastrintestinais em caprinos e ovinos da região oeste do Rio Grande do Norte, Brasil. Ciênc Anim Bras 2008; 9(1): 212-218.

Blotkamp J, Krepel HP, Kumar V, Baeta S, Van't Noordende JM, Polderman AM. Observations on the morphology of adults and larval stages of Oesophagostomum sp. isolated from man in northern Togo and Ghana.J Helminthol 1993; 67(1): 49-61. PMid:8509618. http://dx.doi. org/10.1017/S0022149X00012840

Chiejina SN, Behnke JM. The unique resistance and resilience of the Nigerian West African Dwarf goat to gastrointestinal nematode infections. Parasit Vectors 2011; 4: 12. http://dx.doi.org/10.1186/1756$3305-4-12$

Costa CAF, Vieira LS, Berne MEA, Silva MUD, Guidoni AL, Figueiredo EAP. Variability of resistance in goats infected with Haemonchus contortus in Brazil. Vet Parasitol 2000; 88(1-2): 153-158. http://dx.doi. org/10.1016/S0304-4017(99)00207-1

Domke AV, Chartier C, Gjerde B, Höglund J, Leine N, Vatn S, et al. Prevalence of anthelmintic resistance in gastrointestinal nematodes of sheep and goats in Norway. Parasitol Res 2012; 111(1): 185-193. PMid:22290446 PMCid:PMC3378835. http://dx.doi.org/10.1007/ s00436-012-2817-x

Felsenstein J. Confidence limits on phylogenies: an approach using the bootstrap. Evolution 1985; 39(4): 783-791. http://dx.doi. org/10.2307/2408678

Gasser RB, Stewart LE, Speare R. Genetic markers in ribosomal DNA for hookworm identification. Acta Trop 1996; 62(1): 15-21. http://dx.doi. org/10.1016/S0001-706X(96)00015-0

Ghadirian E, Arfaa F. First report of human infection with Haemonchus contortus, Ostertagia ostertagi, and Marshallagia marshalli (family Trichostrongylidae) in Iran. J Parasitol 1973; 59(6): 1144-1145. http:// dx.doi.org/10.2307/3278661

Gordon HML, Whitlock HV. A new technique for counting nematode eggs in sheep faeces. J Council Sci Ind Res Aust 1939; 12(1): 50-52.

Hall TA. BioEdit: a user-friendly biological sequence alignment editor and analysis program for windows 95/98/NT. Nucleic Acids Symp Ser 1999; 41: 95-98.
Hassan MM, Hoque MA, Islam SKMA, Khan SA, Roy K, Banu Q. A prevalence of parasites in black bengal goats in Chittagong, Bangladesh. Int J Livest Prod 2011; 2(4): 40-44.

Holmes PH. Pathogenesis of Trichostrongylosis. Vet Parasitol 1985; 18(2): 89-101. http://dx.doi.org/10.1016/03044017(85)90059-7

Honer MR, Vieira-Bressan MCR. Cattle nematodes in Brazil - the state of research, 1991. Rev Bras Parasitol Vet 1992; 1(1): 67-79.

Kumar S, Tamura K, Nei M. MEGA3: Integrated software for Molecular Evolutionary Genetics Analysis and sequence alignment. Brief Bioinform 2004; 5(2): 150-163. PMid:15260895. http://dx.doi. org/10.1093/bib/5.2.150

Lattes S, Ferte H, Delaunay P, Depaquit J, Vassallo M, Vittier M, et al. Trichostrongylus colubriformis Nematode Infections in Humans, France. Emerg Infect Dis 2011; 17(7): 1301-1302. PMid:21762594 PMCid:PMC3381412. http://dx.doi.org/10.3201/eid1707.101519

Perry BD, Randolph TF. Improving the assessment of the economic impact of parasitic diseases and of their control in production animals. Vet Parasitol 1999; 84(3-4): 145-168. http://dx.doi.org/10.1016/S03044017(99)00040-0

Ratanapob N, Arunvipas P, Kasemsuwan S, Phimpraphai W, Panneum $S$. Prevalence and risk factors for intestinal parasite infection in goats raised in Nakhon Pathom Province, Thailand. Trop Anim Health Prod 2012; 44(4): 741-745. PMid:21833677. http://dx.doi.org/10.1007/ s11250-011-9954-6

Roberts FHS, O’Sullivan PJ. Methods for egg counts and larval cultures for strongyles infesting the gastro-intestinal tract of the cattle. Aust J Agric Res 1950; 1(1): 99-102. http://dx.doi.org/10.1071/AR9500099

Sato M, Sanguankiat S, Yoonuan T, Pongvongsa T, Keomoungkhoun M, Phimmayoi I, et al. Copro-molecular identification of infections with hookworm eggs in rural Lao PDR. Trans $R$ Soc Trop Med Hyg 2010; 104(9): 617-622. PMid:20673938. http://dx.doi. org/10.1016/j.trstmh.2010.06.006

Sato M, Yoonuan T, Sanguankiat S, Nuamtanong S, Pongvongsa T, Phimmayoi I, et al. Short report: Human Trichostrongylus colubriformis infection in a rural village in Laos. Am J Trop Med Hyg 2011; 84(1): 52 54. PMid:21212201 PMCid:PMC3005505. http://dx.doi.org/10.4269/ ajtmh.2011.10-0385

Sweeny JP, Gardner GE, Dobson RJ, Jacobson C, Bell K. Associations between trichostrongylid worm egg count and productivity measures in Dorper lambs. Vet Parasitol 2011; 180(3-4): 307-314. PMid:21466922. http://dx.doi.org/10.1016/j.vetpar.2011.03.015

Ueno H, Gonçalves PC. Manual para diagnóstico das helmintoses de ruminantes. Tokio: Japan International Cooperation Agency; 1998. 